\title{
The Impact of Agricultural Improvement Intervention Through Market Development on the Livelihoods of Rural Farmers in Ethiopia: A Propensity Score Maching Application
}

\author{
Wole Kinati ${ }^{\circ}$
}

\author{
${ }^{1}$ Oromia Agricultural research Institute, Ethiopia
}

\begin{abstract}
A market development program to enhance production, productivity and income of rural peoples was jointly implemented by the government and NGOs in rural Ethiopia from 2009 to 2012. It was claimed to be successful on different occasions creating an interest among policy makers, development practitioners and researchers to quantify the impacts of the intervention. Acoordingly, in 2013, data were collected from a total of 201 farm households comprising both participating and non-participating but comparative groups of farm households. The current study aimed at answering the questions of what changes were brought in the organizational and institutional aspect of the agricultural input/output marketing in the pilot implementation areas as a result of the intervention and what would have been the market orientation, participation, productivity and income outcomes of participating households if the intervention had not been in place. Using Propensity Score Matching (PSM), after controlling for the initial differences, the result of our impact estimate revealed that the program significantly raised the intensity of input use, productivity, commercial orientation and proportion of sales of most of the commodities of intervention for participant households leading to a significant increase in cumulative net income by about $10 \%$. Although the results have shown that the program had succeeded in achieving the ultimate objective of the program, further research is recommended to elicit information on how the benefits were distributed among the different categories of participants and the relative contribution of each commodities of intervention to the outcome variables.
\end{abstract}

Keywords: Impact, Market Development, PSM

\section{Introduction}

The recent move towards the liberalization of foreign direct investment in developing countries and the subsequent structural adjustment programs in many Sub-Saharan African countries have liberalized their economies and formulated poverty reduction strategies that are intended to open-up new marketled opportunities for economic growth. Like many developing countries, Ethiopia has undergone several structural adjustment programs in the past few decades that aimed at bringing economic growth thus reduce poverty. A pillar of the country's recent rural development strategy has been the active promotion of marketing cooperatives as a means of commercializing smallholder agriculture.

The recently formulated strategy of the country has emphasized on the transformation of subsistence agriculture into market oriented patterns of production as a basis for long-term development of the agricultural sector. Currently, several programs are under way both by government and nongovernment institutions so as to realize the strategy. In view of this, the regional research institute and government of Oromia initiated a joint program on introduction of improved agricultural technologies and input/output marketing to facilitate the development of marketable commodities implemented from 2009 to 2012.

The project focused on the value chain approach by encouraging the involvement of actors along the value chains so that the experience generated would be scaled up to similar areas in the region. Kofale district of the Arsi Zone was selected based on its potential for the selected commodities of interventions which includes inset and fruit cultivation, apiculture and fattening implemented as a pilot project primarily to raise the income level of participant households through market development. The current study seeks to answer two research questions; what changes were brought in the

This article is published under the terms of the Creative Commons Attribution License 4.0

Author(s) retain the copyright of this article. Publication rights with Alkhaer Publications.

Published at: http://www.ijsciences.com/pub/issue/2018-02/

DOI: 10.18483/ijSci.918; Online ISSN: 2305-3925; Print ISSN: 2410-4477 
institutional aspect of agricultural input/output marketing in the pilot district as a result of the intervention? And what would have been the market orientation, participation, productivity and income outcomes of participating households if the intervention had not been in place?

\section{Research Methodology \\ Data Sources, Sampling and Collection Techniques}

The study used both qualitative and quantitative data collected from secondary and primary sources. Secondary data related to the study were collected from project reports, Zonal and regional offices of Agriculture and Rural Development and APEDO of the pilot zone. Whereas primary data were collected from randomly selected farm households from both participants and non-participants using formal survey by the project staff.

In doing so, all the five pilot kebels where the project implemented and another five Kebeles outside the project area within the same pilot district were selected as control based on their similarity in socioeconomic and agroecological characteristics with the target kebeles. Moreover, in selecting the control kebeles, their accessibility to main road and agricultural extension services, and their potential opportunity for the specific commodity of intervention were considered. In addition, their geographical location (non-adjacent kebeles) was taken into account so that information flow from participant to non-participant kebeles minimized. Following the identification of the participant and eligible non-participant, a total of 201 farm households (100 from participant and 101 from nonparticipant households) were randomly drawn based on probability proportional to sample size. In the months of February and March, 2013, the project staff administered the same structured questionnaire to the selected participant and non-participant households in order to collect data on a variety of topics.

Using the structured questionnaire, information on outcome variables and different topics that include household resource endowments, access to agricultural and markets services, and demographic characteristics of the respondents were collected from both groups. In addition to the data collected by the use of structured questionnaire, informal communications through telephone and e-mails was made with project staff, district and kebele experts, and representatives of farmers' associations in order to generate additional information that was useful to understand and better describe the overall project situations and enrich the interpretations of the result of qualitative analysis.

\section{Analytical Methodology}

The qualitative information generated from secondary sources and informal interviews on changes in the institutional aspect of agricultural input and output marketing in the district as a result of the intervention were narrated and described qualitatively. These results from the qualitative analysis were also used to supplement the results from the quantitative analysis. Moreover, descriptive statistics such as mean, standard deviation, percentages and cross tabulations were used in analyzing the data collected through formal surveys by employing SPSS.

In order to deal with the research questions at hand, a non-experimental method called propensity score matching (PSM) was employed as the best alternative analytical method available to estimate the impact of the intervention based on the available data at hand. We selected PSM among the available nonexperimental methods because of three reasons: (1) baseline date was not available for the project, (2) treatment assignment was not based on random, and (3) PSM is assumed as the second best alternative available to that of experimental design in minimizing selection bias (Baker, 2000).

Using the propensity score estimated by the use of logit model, match pairs are constructed using alternative kernel matching algorithms which was found to be suitable for the data at hand. Then the impact of an intervention was computed as the difference between the simple mean of the outcome variable of interest for participant and non participant households. Accordingly, ATT is obtained by averaging these differences in outcome variable/s $\left(Y_{i}\right)$ across the $k$ matched pairs of households as follows:

$\mathrm{ATT}=\frac{1}{\mathrm{~K}} \sum_{\mathrm{i}=1}^{\mathrm{K}}\left[\mathrm{Y}_{\mathrm{i}}^{\mathrm{i} \in \mathrm{D}=1}-\mathrm{Y}_{\mathrm{i}}^{\mathrm{i} \in \mathrm{D}=0}\right]$

The result computed by this equation can be taken as the impact of the program and hence a positive or negative value of ATT suggests that participant households have higher or lower of outcome variable $Y_{\mathrm{i}}$ than non-participants.

\footnotetext{
Choice of Variables for Logit Model, Indicators of Outcome Variables and thier Measurment

In general, the choice of covariates for the propensity score model should be based on theory and previous empirical findings (Black and Smith, 2004; Heckman et al, 1998). It is suggested that only variables that affect simultaneously the treatment status and the outcome variable need to be included (Sianesi, 2004).
} 
Given that unconfoudedness assumption ${ }^{1}$ requires the outcome variable(s) to be independent of treatment assignment conditional on the propensity score and thus one must choose a set of covariates that credibly satisfy this condition. In other words, only variables that are unaffected by treatment need to be included in the model. To ensure this, therefore, variables should either be fixed over time (time invariant) or measured before participation. For the current study, since there have been no data available before intervention for the program, only time invariant household characteristics were feasible to include in the model and hence variables that are fixed over time were used.

In the current study, four variables were considered as outcome indicators. These are productivity, market surplus, net income and proportion of resources allocated (as indicators of market orientation).

Intensity and productivity is measured by the quantity of inputs used for the market oriented commodities of interventions and the ratio of a measure of total output quantity to measure of the quantity of total input (Liverpool-Tasie et al, 2011). The project has facilitated input supply by engaging and supporting the different actors so that participant households had access to agricultural inputs which are very important to increase productivity. Households required extra labor in addition to the family labor for specific commodities like inset especially during peak season (like harvesting). Therefore, for this particular commodity, the intensity of labor use was measured using person days.

Marketed surplus, according to Wolday (1994) is the quantity of a commodity actually sold in the market without meeting farmers' consumptions and utilization requirement. The project intervention is expected to improve the quantity of produce taken to the market and this market surplus was measured as the percentage increase in volume. Household net income is the net income generated as a result of household's participation in the program and measured in Birr. It is the difference between the total revenue and the total cost incurred by the household for the generation of that revenue for the commodities of intervention. Following the approaches adopted by Berhanu and Dirk (2009), the proportion of land allocated for specific commodities, possession of improved bee hives for apiculture and the number of sheep allocated for fattening were used

\footnotetext{
${ }^{1}$ The unconfoudedness assumption states that conditional on $X$, non-participant outcomes have the same distribution that participants would have experienced if they had not participated in the programme and vice versa (Caliendo and Kopeinig, 2008).
}

to estimate the impact of the program on the market orientation behavior of participant households.

\section{Results and Discussion}

\section{Institutional Arrangements Involving and linking value chain actors along the value chain}

The project facilitated and supported the involvement of these actors along the value chain to enable them play the important different roles that support target households so that farmers had improved access to a variety of services so that their agricultural production and productivity could be improved; thier market involvement would be enhanced and ultimately thier income level would be raised. It was obsereved from the interview held with key informants, there were better involvement of key stakeholders along the value chains of commodities of intervention which resulted in better production and productivity improving income levels of participant households. The different stakeholders involved and the roles they played during the intervention as reported and witnessed by district experts and farmers' representatives was summarized below in Table 1. 
The Impact of Agricultural Improvement Intervention Through Market Development on the Livelihoods of Rural Farmers in Ethiopia: A Propensity Score Maching Application

Table 1. Types and roles of stakeholders involved along the value chains of commodities of intervention

\begin{tabular}{|c|c|c|c|}
\hline Stakeholders & Role and responsibilities & $\begin{array}{l}\text { Types of } \\
\text { commodities } \\
\text { supported }\end{array}$ & $\begin{array}{l}\text { Level of thier } \\
\text { involvement }\end{array}$ \\
\hline Kebele administration & $\begin{array}{l}\text { Mobilize farmers, facilitate linkage between } \\
\text { farmers and other supporting actors, support } \\
\text { learning and experience sharing events }\end{array}$ & $\begin{array}{l}\text { All target } \\
\text { commodities }\end{array}$ & High \\
\hline $\begin{array}{l}\text { District office of } \\
\text { agriculture \& rural } \\
\text { development }\end{array}$ & $\begin{array}{l}\text { Provide technical support, support other actors } \\
\text { involved in the program, facilitate and support } \\
\text { different activities useful to farmers }\end{array}$ & $\begin{array}{l}\text { All target } \\
\text { commodities }\end{array}$ & High \\
\hline Research centers & $\begin{array}{l}\text { Provide training, technical backup, basic } \\
\text { improved technologies and host experience } \\
\text { sharing tours/visits }\end{array}$ & $\begin{array}{l}\text { All target } \\
\text { commodities }\end{array}$ & High \\
\hline $\begin{array}{l}\text { Livestock Development } \\
\text { Agency }\end{array}$ & $\begin{array}{l}\text { Provide technical support and market } \\
\text { information }\end{array}$ & $\begin{array}{l}\text { Small ruminant } \\
\text { fattening and } \\
\text { apiculture }\end{array}$ & Medium \\
\hline $\begin{array}{l}\text { Concentrate feed \& by- } \\
\text { product suppliers }\end{array}$ & $\begin{array}{l}\text { Supply concentrates feed to farmers engaged } \\
\text { in fattening activities }\end{array}$ & $\begin{array}{l}\text { Small ruminant } \\
\text { fattening }\end{array}$ & High \\
\hline $\begin{array}{l}\text { Public \& private } \\
\text { veterinary service } \\
\text { providers }\end{array}$ & $\begin{array}{l}\text { Provide veterinary services to target } \\
\text { households facilitated by development agents }\end{array}$ & $\begin{array}{l}\text { Small ruminant } \\
\text { fattening }\end{array}$ & Medium \\
\hline $\begin{array}{l}\text { Local saving and credit } \\
\text { groups (informal) }\end{array}$ & $\begin{array}{l}\text { Provide financial services to target households } \\
\text { and needy private traders involved in the } \\
\text { value chain facilitated by the project }\end{array}$ & $\begin{array}{l}\text { All target } \\
\text { commodities }\end{array}$ & High \\
\hline $\begin{array}{l}\text { Village level input } \\
\text { suppliers (private) }\end{array}$ & $\begin{array}{l}\text { Supply locally produced important } \\
\text { agricultural inputs demanded by target } \\
\text { households }\end{array}$ & $\begin{array}{l}\text { All target } \\
\text { commodities }\end{array}$ & High \\
\hline Local honey traders & $\begin{array}{l}\text { Buy honey from target households and sell to } \\
\text { other middlemen or supermarkets }\end{array}$ & Apiculture & Medium \\
\hline $\begin{array}{l}\text { Local carpenters and } \\
\text { foundation sheet sellers }\end{array}$ & $\begin{array}{l}\text { Construct improved bee hives and produce } \\
\text { foundation sheet supported by experts from } \\
\text { research centers and sell to beekeepers }\end{array}$ & Apiculture & High \\
\hline Farmer cooperatives & $\begin{array}{l}\text { Provide different inputs demanded by farmers } \\
\& \text { collect and market products from members } \\
\text { with premium price }\end{array}$ & $\begin{array}{l}\text { All target } \\
\text { commodities }\end{array}$ & High \\
\hline OCSSC & $\begin{array}{l}\text { Provide credit services and financial } \\
\text { management trainings to target households }\end{array}$ & $\begin{array}{l}\text { All target } \\
\text { commodities }\end{array}$ & Low \\
\hline
\end{tabular}

Source: Own based on online consultation with OBoARD and Kebele leaders, farmers' representatives and secondary sources

However, although the project creates business opportunities for small scale traders so that target households' access to agricultural inputs would be improved, peer group collateral arrangement hampered revolving of credit funds as a result of delayed loan repayment by some of the traders. They also not well aware of the working principles that OCSSC follows in providing credit services. Hence, some of the traders quit their work affecting farmers' access to the inputs as the district officials witnessed (online interview, 13 July 2013). Reducing the size of collateral group to optimum number, looking for other options as alternative to group lending, for example encouraging and introducing private saving could be explored. Moreover, in order to improve the linkage between the organized small scale traders, financial service providers and other actors in the system, integrating saving and credit and financial management trainings into rural financial service provision is essential.

\section{Enhancing farmers' capacity}

In order to enhance the production and productivity of the target households, the project recognized the importance of continued capacity building through different means. Accordingly, different trainings on a variety of topics were facilitated and organized throughout the project life. As part of capacity building, several experience sharing and study tours were also conducted for selected farm households so that they were later used as resource farmers for their community to teach other farmers in their vicinity. Research centers were used as the main actors in this regard. Apart from providing improved technologies, 
they involved in the capacity building programs of the project by sending trainers and technical advisors throughout the training programs. As a result, target households were benefited from the training programs in the course of exercising the application and use of new technologies (OBoARD, 2013).

\section{Emperical result}

The descriptive analysis of the effect of the program on outcome variables suggests that participant households performed much better in most of the outcome variables (look at Annexes Table 5). However, similar analyses of household characteristics revealed that there are also substantial differences in the underlying characteristics of participant versus non-participant households. Therefore, based on a simple comparison of means without controlling for these differences, it is impossible to identify causality and to attribute the observed differences in all the outcome variables to the impact of the program. Hence, in the subsequent sections we presented an econometric analysis that was used to estimate the causal impact of participation in the program mainly on household productivity, market orientation and participation, and income outcomes.

\section{Estimating treatment effect on the treated}

The results of our estimate of the impact of agricultural improvement intervention through market development after controlling for observable confounding factors suggest that the program was found improving intensity of input use, productivity, commercial orientation and proportion of sales of most of the commodities of intervention for participant households eventually increasing their income (Table 2). Specifically, we found a statistically significant program effect for intensity of input use for inset cultivation and small ruminant fattening $(\mathrm{P}<0.01)$. This result is in line with the findings of Deschamps-Laporte (2013) and Mendola (2006). In the context of the study area, input used for these program activities, inset cultivation and small ruminant fattening, was mainly accessed by program participant households through marketing from other sources facilitated by the program. This means that the program has improved the average use of these inputs for participant households. Moreover, as argued by Goetz (1992), is being a net buyer in the market determine the extent of once market participation. Higher market participation drives more productivity by providing incentives for the households (Reardon and Timmer, 2005).

Similarly, the empirical analysis for the productivity of commodities of intervention for which data is available suggests that there is statistically significant difference between participant and non-participant households. The program was found improving the productivity of inset and honey by about $12 \%$ and $9 \%$ for participant households respectively $(\mathrm{P}<0.01$ and $\mathrm{P}<0.1)$. The result for inset productivity is, of course, in line with one's expectation as the previous results of input use for this particular commodity is significantly higher for participant than that of nonparticipant households. However, the striking result for the productivity of honey for which there is no statistically significant difference in terms of input use between the groups might be attributed to the difference in management practices between them as a result of the simultaneous capacity development intervention for participant households as discussed under the qualitative analysis section.

In the same way, our analysis also clearly demonstrated that the program had a significant and posetive effect on the quantities of produce taken to the market for inset, honey and fattend small ruminants. More specifically, participant households increased the proportion of their produce marketed on average by $4 \%, 12 \%$ and $18 \%$ respectively for the indicated commodities of intervention. This implies that the program enhenced target household's participation in the market as a result of higher productivity.

Based on the concept of commercialization measurement which states that commercialization can be measured in terms of the degree of allocation of the different resources such as labor and land to competing agricultural activities and total sales of agricultural commodities (Keister and Nee, 2001), we measured the effect of the program on the level of households' commercialization by comparing these indicators between the two groups. Accordingly, our estimate revealed that the program has achieved improving the levels of resource allocated to and possession of market oriented commodities. More precisely, the program helped participant households to increase the allocation of land and small ruminant for market oriented activities by about $14 \%$ and $44 \%$ respectively while improving the possession of improved beehives by about $30 \%$. The result is also significant at a $1 \%$ and $10 \%$ probability levels respectively (Table 2). Households' decision to increase resource allocation and possession of commercial oriented resources, in this case, could be stimulated due to market signals as a result of their improved access to market facilitated by the program (Berhanu and Dirk, 2009; Pingali, 1997). Moreover, the involvement of relevant actors across the value chains as depicted by the results of our qualitative analysis could also be part of the reason. 
Table 2. Estimated ATT for the outcome variables

\begin{tabular}{|c|c|c|c|c|c|}
\hline \multirow[b]{2}{*}{ Outcome variables } & \multicolumn{3}{|c|}{ Nonparticip } & \multirow[b]{2}{*}{ S.E } & \multirow[b]{2}{*}{ t-value } \\
\hline & Participant & ant & Difference & & \\
\hline \multicolumn{6}{|l|}{ Intensity of Input use } \\
\hline $\begin{array}{l}\text { Intensity of labor use for inset } \\
\text { cultivation (PD) }\end{array}$ & 108.677 & 89.6455 & 19.0319 & 6.363 & $2.99 * * *$ \\
\hline $\begin{array}{l}\text { Additional tools used for inset } \\
\text { cultivation (No.) }\end{array}$ & 3.3596 & 1.0484 & 2.3112 & 0.159 & $14.51 * * *$ \\
\hline $\begin{array}{l}\text { Value of input used for apiculture } \\
\text { (Birr) }\end{array}$ & 62.1930 & 56.5350 & 5.6580 & 28.56 & 0.20 \\
\hline $\begin{array}{l}\text { Quantity of cotton meal used for } \\
\text { fattening }(\mathrm{Kg})\end{array}$ & 97.6136 & 3.7869 & 93.8268 & 8.984 & $10.4 * * *$ \\
\hline Value of input use for fattening (Birr) & 847.024 & 83.6408 & 763.3839 & 91.13 & $8.4 * * *$ \\
\hline Value of input use for fruit(Birr) & 61.4944 & 56.2478 & 5.2466 & 28.44 & 0.18 \\
\hline \multicolumn{6}{|l|}{ Productivity } \\
\hline Productivity of inset (Quintal/ha) & 1413.15 & 1242.827 & 170.3203 & 70.21 & $2.43 * *$ \\
\hline $\begin{array}{l}\text { Productivity of improved hives } \\
\text { (Kg/hive) }\end{array}$ & 28.468 & 25.7934 & 2.6754 & 1.477 & $1.81 *$ \\
\hline \multicolumn{6}{|l|}{ Commercial Orientation } \\
\hline Land allocated for inset (\%) & 0.6713 & 0.5754 & 0.0960 & 0.040 & $2.39 * * *$ \\
\hline Possessions of improved hives (\%) & 0.4270 & 0.2987 & 0.1283 & 0.074 & $1.73^{*}$ \\
\hline Sheep allocated for fattening (No.) & 5.2830 & 2.9711 & 2.3120 & 0.427 & $5.41 * * *$ \\
\hline \multicolumn{6}{|l|}{ Proportion of sales } \\
\hline Sale of inset $(\%)$ & 0.8232 & 0.7812 & 0.0420 & 0.012 & $3.41 * * *$ \\
\hline Sale of honey $(\%)$ & 0.6981 & 0.5832 & 0.1149 & 0.040 & $2.89 * * *$ \\
\hline Sale of fattened small ruminant $(\%)$ & 0.9433 & 0.7573 & 0.1827 & 0.052 & $3.54 * * *$ \\
\hline Sale of fruit seedling $(\%)$ & 0.5815 & 0.5702 & 0.0112 & 0.278 & 0.04 \\
\hline \multicolumn{6}{|l|}{ Average net income } \\
\hline Total net income & 5757.38 & 5200.388 & 556.9964 & 94.65 & $5.9 * * *$ \\
\hline
\end{tabular}

Note: ***, ** and * means significant at the 1\%, 5\% and $10 \%$ probability levels, respectively

Source: Own calculation based on the survey data

As stated earlier, the ultimate objective of the current program under consideration was to improve the income of participant household from increased participation in the production and marketing of commercial oriented agricultural inputs and outputs. Based on the available data, we measured the impact of the program on the income of participant households. Accordingly, the result of our estimation indicated that the program has significantly increased the cumulative net income of households who participated in the program by about $10 \%(\mathrm{P}<0.01)$. This finding was consistent with the findings reported by Egziabher et al (2013) who evaluated the impact of the IHEP program on the income of participant households in the northern part of Ethiopia and reported similar results. The effect of the program on net income of participant households is, of course, in line with one's expectation since the program succeeded in significantly improving the levels of input use, resource allocation, productivity, and market participation of its target households.

\section{Conclusion and Recommendation}

This study provides crucial insights into and important evidence on the impact of agricultural improvement interventions through market development on the livelihoods of farmers in rural Ethiopia using cross sectional data collected in the beginning of 2013 . Using matching estimator, the study evaluated the program implemented jointly by the Regional Bureau of Agriculture and Research Institute between 2009 and 2012.

The qualitative analysis has shown that the program has improved the linkages and interaction among different actors along the value chains of the commodities of intervention. By doing so, participant households' access to different agricultural inputs and outputs marketing services have been enhanced although the level of involvement and service delivery by some of the actors (like OCSSC) are not satisfactory as pointed out by respondents as a results of the institutional arrangements in place. 
After controlling for these initial differences, our impact estimate using PSM suggested that the program significantly raised the intensity of input use, commercial orientation, productivity, and proportion of sales of most of the commodities of intervention for participant households eventually increasing their income. Although the results of our impact estimation confirmed that the program had succeeded in improving the income level (the ultimate objective of the program) of participating households, further evidences are required that elucidate how the benefits were distributed among the different categories of participants like poor, rich and women within the targeted households. As evidences from literature pointed out that there are firm criticizes about the popular understanding that assumes participation of the poor in development interventions ensures equitable benefit (Cleaver and Hamada, 2010). Similarly, it is also interesting to investigate through further research the reason behind why households with relatively large family size are less likely to participate as this study revealed. Moreover, it is also apparent that further study is required with sufficient sample size to explore the relative contribution of each commodities of intervention that might help the regional government in order to consolidate efforts in the course of extending the experience of the program as the current study did not capture these due to lack of data. Finally, it is also worthy revisiting the institutional arrangements adopted by rural financial institutions like OCSSC to further enhance households' access to financial services.

\section{BIBLIOGRAPHY}

1. Baker, J.L. (2000) Evaluating the impact of development projects on poverty: A handbook for Practitioners, Washington D.C., World Bank.

2. Berhanu Gebremedhin and Dirk, H. (2009) Staple food crops turning into commercial crops: Case studies of Teff, Wheat and Rice in Ethiopia. Revision submitted to the Ethiopian Journal of Economics. International Livestock Research Institute (ILRI). Addis Ababa, Ethiopia.

3. Caliendo, M. and Kopeinig, S. (2008) "Some practical guidance for the implementation of propensity score matching" IZA Discussion Paper No. 1588, University of Cologne.

4. Cleaver, F. and Hamada, K. (2010) “'Good' Water Governance and Gender Equity: a Troubled Relationship", Gender and Development, 18(1): 27-41.

5. Egziabher, G.K., Mathijs, E., Deckers, J., Gebrehiwot, K., Bauer, H. and Maertens, M. (2013) "The Economic Impact of a New Rural Extension Approach in Northern Ethiopia" Bioeconomics Working Paper Series, Department of Earth and Environmental Sciences, University of Leuven.

6. Heckman, J.J., Ichimura, H., Smith, J. and Todd, P. (1998) "Characterizing selection bias using experimental data", Econometrica, 66: 1017-1098.

7. Keister, L.A. and Nee, V.G. (2001) "The rational peasant in China. Flexible adaptation, risk diversification and opportunity", Rationality and Society, 13 (1).

8. Liverpool-Tasie, L.S., Kuku, O., Ajibola, A. (2011) “A Review of Literature on Agricultural Productivity, Social Capital and Food Security in Nigeria” IFPRI, NSSP Working Paper 21.

9. Mendola, M., (2006) "Agricultural technology adoption and poverty reduction: A propensity score matching analysis for rural Bangladesh", Food Policy, 32(3): 372-393.

10. OBOARD (Oromia Bureau of Agriculture and Rural Development) (2011) “Annual Report on the Progress of Agricultural Improvement Intervention through Market Development Intervention in Kofale Woreda" Arsi Zone, Oromia National Regional State.

11. OBoARD (Oromia Bureau of Agriculture and Rural Development) (2013) "Annual Report on the Progress of Agricultural Improvement Intervention through Market Development Intervention in Kofale Woreda" Arsi Zone, Oromia National Regional State.

12. Pingali, P. (1997) "From subsistence to commercial production systems: The transformation of Asian agriculture", American Journal of Agricultural Economics, 79(2): 628-634.

13. Reardon, T. and Timmer, C.P. (2005) "Transformation of Markets for Agricultural Output in Developing Countries Since 1950: How Has Thinking Changed", in: Evenson, R.E., Pingali, P. and Schultz, T.P. (eds) Agricultural Development, Amsterdam, 135-149.

14. Sianesi, B. (2004) "An evaluation of the active labour market programs in Sweden" The Review of Economics and Statistics, 186(1):133-155.

15. Wolday A. (1994) "Food grain marketing development in Ethiopia after the market reform 1990, A case study of Alaba Siraro district" PhD Dissertation, Veriog Koster, Berlin, Germany. 
The Impact of Agricultural Improvement Intervention Through Market Development on the Livelihoods of Rural Farmers in Ethiopia: A Propensity Score Maching Application

\section{Annex}

Table 1. Sample size by Kebele

\begin{tabular}{|c|c|c|c|c|c|c|c|}
\hline \multicolumn{4}{|c|}{ Project targeted Kebeles } & \multicolumn{4}{|c|}{ Non-targeted (Control) Kebeles } \\
\hline Sample Kebeles & $\begin{array}{c}\text { Participant } \\
H H s\end{array}$ & $\bar{N}$ & $\%$ & $\begin{array}{l}\text { Sample } \\
\text { Kebeles }\end{array}$ & Total eligible $\mathrm{HHs}$ & $N$ & $\%$ \\
\hline We/Bendelichu & 131 & 16 & 16 & Garmama & 1882 & 32 & 32 \\
\hline Ro/Ashoka & 270 & 31 & 31 & $\begin{array}{l}\text { Wamanye } \\
\text { Alkeso }\end{array}$ & 1200 & 21 & 21 \\
\hline We/Abosa & 233 & 28 & 28 & Quma Mamo & 1313 & 23 & 23 \\
\hline We/Wolu & 151 & 18 & 18 & $\begin{array}{l}\text { Abosa } \\
\text { Adamonye }\end{array}$ & 918 & 16 & 16 \\
\hline $\begin{array}{l}\text { Benjo Ashoka } \\
\text { Total }\end{array}$ & $\begin{array}{c}56 \\
841\end{array}$ & $\begin{array}{c}7 \\
100\end{array}$ & $\begin{array}{c}7 \\
100\end{array}$ & $\begin{array}{l}\text { Guchi } \\
\text { Total }\end{array}$ & $\begin{array}{c}544 \\
\mathbf{5 8 5 7}\end{array}$ & $\begin{array}{c}9 \\
101\end{array}$ & $\begin{array}{c}9 \\
101\end{array}$ \\
\hline
\end{tabular}

Table 2. Variables used for Logit Model

\begin{tabular}{|c|c|c|}
\hline Variables & Description & Types and Measurements \\
\hline \multicolumn{3}{|c|}{ Dependent variables } \\
\hline TYPFRMER & $\begin{array}{l}\text { Participation in the } \\
\text { intervention }\end{array}$ & Dummy, 1 if yes, 0 otherwise \\
\hline \multicolumn{3}{|c|}{ Independent variables } \\
\hline SEXHH & Sex of the respondent & Dummy, 1 if male, 0 otherwise \\
\hline AGEHH & Age of the household head & Discrete, in years \\
\hline EDULVLHH & $\begin{array}{l}\text { Education level of household } \\
\text { head }\end{array}$ & Dummy, 1 if read and write, 0 otherwise \\
\hline TOTLFMSZ & $\begin{array}{l}\text { Total family size of the } \\
\text { household }\end{array}$ & Discrete, number of household members \\
\hline EXPFRMG & $\begin{array}{l}\text { Farming experience of the } \\
\text { household head }\end{array}$ & Discrete, in years \\
\hline SZEOWNLN & Total land owned & Continuous, in hectare \\
\hline DISTMKTN & Distance to the nearest market & Continuous, in kilometers \\
\hline DISTEXTO & Distance to extension office & Continuous, in kilometers \\
\hline
\end{tabular}

Table 3. T-test for equality of means between groups (continuous variables)

\begin{tabular}{|c|c|c|c|c|c|c|c|}
\hline \multirow[t]{2}{*}{ HH characteristics } & \multicolumn{2}{|c|}{$\begin{array}{l}\text { Participant } \\
(\mathrm{N}=100)\end{array}$} & \multicolumn{2}{|c|}{$\begin{array}{l}\text { Nonparticipant } \\
\text { (101) }\end{array}$} & \multicolumn{2}{|c|}{$\begin{array}{l}\text { Difference in } \\
\text { means }\end{array}$} & \multirow[t]{2}{*}{ t-value } \\
\hline & Mean & STD & Mean & STD & Mean & STD $^{2}$ & \\
\hline Age of HH head (years) & 43.95 & 8.710 & 44.090 & 7.482 & -0.139 & 1.145 & -0.121 \\
\hline Total family size & 5.240 & 2.046 & 6.390 & 2.249 & -1.146 & 0.303 & $-3.78 * * *$ \\
\hline $\begin{array}{l}\text { Farming experience of } \mathrm{HH} \\
\text { head (in years) }\end{array}$ & 22.71 & 6.927 & 22.850 & 6.842 & -0.141 & 0.971 & -0.146 \\
\hline Size of ownd land (ha) & 1.213 & 0.950 & 1.024 & 0.643 & 0.194 & 0.115 & $1.688 *$ \\
\hline $\begin{array}{l}\text { Distance from market center } \\
(\mathrm{km})\end{array}$ & 1.500 & 1.518 & 2.376 & 1.996 & -0.876 & 0.250 & $-3.51 * * *$ \\
\hline $\begin{array}{l}\text { Distance from extension office } \\
(\mathrm{km})\end{array}$ & 2.306 & 1.297 & 3.452 & 1.722 & -1.147 & 0.215 & $-5.34 * * *$ \\
\hline \multicolumn{8}{|c|}{$\begin{array}{l}\text { Note: } * * * \text { and } * * \text { means significant at the } 1 \%, 10 \% \text { probability levels, respectively }(t \text {-test is used for differences in } \\
\text { means) }\end{array}$} \\
\hline
\end{tabular}


The Impact of Agricultural Improvement Intervention Through Market Development on the Livelihoods of Rural Farmers in Ethiopia: A Propensity Score Maching Application

Table 4. Chi-square test for equality of proportions between groups (dummy variables)

\begin{tabular}{|c|c|c|c|c|c|c|c|c|}
\hline \multirow{2}{*}{$\begin{array}{c}\text { HH } \\
\text { characteristics }\end{array}$} & \multirow[b]{2}{*}{ Category } & \multicolumn{2}{|c|}{ Participant } & \multicolumn{2}{|c|}{ Nonparticipant } & \multicolumn{2}{|c|}{ Total } & \multirow[t]{2}{*}{$\mathbf{X}^{2}$} \\
\hline & & $\mathrm{N}$ & $\%$ & $\mathrm{~N}$ & $\%$ & $\mathrm{~N}$ & $\%$ & \\
\hline \multirow[t]{2}{*}{ Sex of HH head } & Male & 90 & 90 & 84 & 84 & 174 & 87 & 2.017 \\
\hline & Female & 10 & 10 & 17 & 17 & 27 & 13 & \\
\hline \multirow[t]{2}{*}{$\begin{array}{l}\text { Educational level } \\
\text { of HH head }\end{array}$} & $\begin{array}{l}\text { Can read \& } \\
\text { write }\end{array}$ & 94 & 94 & 87 & 87 & 181 & 90 & $3.47 * * *$ \\
\hline & $\begin{array}{l}\text { Cannot read \& } \\
\text { write }\end{array}$ & 6 & 6 & 14 & 14 & 20 & 10 & \\
\hline
\end{tabular}

Source: Own calculation based on the survey data

Table 5. t-test for equality of means between groups for outcome variables

\begin{tabular}{|c|c|c|c|c|c|}
\hline \multirow[t]{3}{*}{ Outcome variables } & \multicolumn{2}{|c|}{ Participant households } & \multicolumn{2}{|c|}{ Nonparticipant households } & \multirow{3}{*}{ t-test } \\
\hline & \multicolumn{2}{|l|}{$(\mathrm{N}=100)$} & \multicolumn{2}{|l|}{$(\mathrm{N}=101)$} & \\
\hline & Mean & SE & Mean & SE & \\
\hline \multicolumn{6}{|l|}{ Intensity of input use } \\
\hline $\begin{array}{l}\text { Intensity of labor use (PDa) for } \\
\text { inset }\end{array}$ & 107.4900 & 2.9200 & 91.2400 & 4.6900 & $2.937 * * *$ \\
\hline $\begin{array}{l}\text { Additional farm tools used for } \\
\text { inset cultivation (No.) }\end{array}$ & 3.3100 & 0.1270 & 1.1300 & 0.0820 & $14.457 * * *$ \\
\hline $\begin{array}{l}\text { Value of input used for } \\
\text { apiculture (Birr) }\end{array}$ & 122.5300 & 24.9840 & 65.4000 & 25.6580 & 1.5950 \\
\hline $\begin{array}{l}\text { Quantity of cotton meal used for } \\
\text { fattening }(\mathrm{Kg})\end{array}$ & 89.4900 & 8.5810 & 4.1600 & 1.5870 & $9.779 * * *$ \\
\hline $\begin{array}{l}\text { Value of fattening input use } \\
\text { (Birr) }\end{array}$ & 776.8820 & 81.7204 & 78.2720 & 26.3108 & $8.137 * * *$ \\
\hline Value of input use for fruit (Birr) & 68.4800 & 19.3130 & 58.6100 & 17.2420 & 0.3810 \\
\hline \multicolumn{6}{|l|}{ Productivity } \\
\hline $\begin{array}{l}\text { Productivity of } \\
\text { inset (Quintal/ha) }\end{array}$ & 1435.740 & 58.7620 & 1291.030 & 33.3900 & $2.141 * *$ \\
\hline Productivity hives (Kg/hive) & 28.2400 & 0.7870 & 25.5800 & 0.8610 & $2.278 * *$ \\
\hline \multicolumn{6}{|l|}{ Commercial orientation } \\
\hline $\begin{array}{l}\text { Land allocated for inset }(\%) \\
\text { Possessions of improved hives } \\
(\%)\end{array}$ & $\begin{array}{l}0.6694 \\
0.4200\end{array}$ & $\begin{array}{l}0.0301 \\
0.0500\end{array}$ & $\begin{array}{l}0.5988 \\
0.3000\end{array}$ & $\begin{array}{l}0.0192 \\
0.0460\end{array}$ & $\begin{array}{l}1.979 * * \\
1.823 *\end{array}$ \\
\hline $\begin{array}{l}\text { Sheep allocated for fattening } \\
\text { (No.) }\end{array}$ & 5.3500 & 0.2570 & 3.5700 & 0.3380 & $4.208 * * *$ \\
\hline \multicolumn{6}{|l|}{ Proportion of sales } \\
\hline Sale of inset $(\%)$ & 0.8235 & 0.0081 & 0.7853 & 0.0070 & $3.556 * * *$ \\
\hline Sale of honey $(\%)$ & 0.7186 & 0.0255 & 0.5839 & 0.0225 & $3.959 * * *$ \\
\hline $\begin{array}{l}\text { Sale of fattened small ruminant } \\
(\%)\end{array}$ & 0.94333 & 0.01177 & 0.75148 & 0.03587 & $5.082 * * *$ \\
\hline Sale of fruit seedling (\%) & 0.08 & 0.02 & 0.09 & 0.021 & -0.255 \\
\hline \multicolumn{6}{|l|}{ Average net income } \\
\hline Total net income & 5778.02 & 47.58 & 5196.06 & 66.67 & $7.105 * * *$ \\
\hline
\end{tabular}


The Impact of Agricultural Improvement Intervention Through Market Development on the Livelihoods of Rural Farmers in Ethiopia: A Propensity Score Maching Application

Table 6. Distribution of estimated propensity scores

\begin{tabular}{llllll}
\hline Variable & Obs & Mean & Std. Dev. & Min. & Max. \\
\hline Total & 201 & 0.498 & 0.247 & 0.025 & 0.970 \\
Participant & 100 & 0.617 & 0.210 & 0.134 & 0.970 \\
Nonparticipant & 101 & 0.379 & 0.220 & 0.025 & 0.863 \\
\hline
\end{tabular}

Table 7. The balancing test before and after matching

\begin{tabular}{|c|c|c|c|c|c|c|}
\hline \multirow[t]{2}{*}{ Variable } & \multicolumn{3}{|c|}{ Before matching } & \multicolumn{3}{|c|}{ After matching } \\
\hline & Treatment & Control & t-value & Treatment & Control & t-value \\
\hline \multicolumn{7}{|l|}{ Continues Variables } \\
\hline _pscore & .62652 & .62166 & 0.17 & .58011 & .48711 & 1.23 \\
\hline $\begin{array}{l}\text { Age of } \mathrm{HH} \text { head } \\
\text { (in years) }\end{array}$ & 43.911 & 43.376 & 0.47 & 43.292 & 43.568 & -0.14 \\
\hline Total family size (No.) & 5.2376 & 5.0891 & 0.44 & 5.4607 & 5.9287 & -0.51 \\
\hline $\begin{array}{l}\text { Farming experience of } \mathrm{HH} \\
\text { head (years) }\end{array}$ & 22.723 & 22.713 & 0.01 & 22.191 & 22.441 & -0.07 \\
\hline Size of owned land (ha.) & 1.2122 & .95911 & $2.15^{* *}$ & 1.0873 & 1.0602 & -0.20 \\
\hline $\begin{array}{l}\text { Distance from the nearest } \\
\text { market center }(\mathrm{km})\end{array}$ & 1.4851 & 1.4554 & 0.13 & 1.5899 & 1.9489 & -0.63 \\
\hline $\begin{array}{l}\text { Distance from extension } \\
\text { office }(\mathrm{km})\end{array}$ & 2.298 & 2.296 & 0.01 & 2.4674 & 2.8464 & -0.85 \\
\hline Dummy Variabels & Treatment & Control & $X^{2}$ & Treatment & Control & $X^{2}$ \\
\hline Sex of HH head (\%) & .90099 & .86139 & 0.87 & .89888 & .86293 & 0.26 \\
\hline $\begin{array}{l}\text { Educational level of } \mathrm{HH} \\
\text { head }(\%)\end{array}$ & .94059 & .9505 & -0.31 & .93258 & .92962 & -0.11 \\
\hline
\end{tabular}

